\title{
Written Testimony of
}

\section{Saule T. Omarova \\ Professor of Law \\ Cornell University}

Before the United States Senate

Committee on Banking, Housing, and Urban Affairs

\section{"Fostering ECONOMic Growth: Midsized, Regional AND LARGE InSTITUTION PERSPECTIVE"}

June 15, 2017

10:00 am

538 Dirksen Senate Office Building

Dear Chairman Crapo, Ranking Member Brown, Members of the Committee:

Thank you for inviting me to testify at this hearing. My name is Saule Omarova. I am Professor of Law at Cornell University, where I teach subjects related to U.S. and international banking law and financial sector regulation. Since entering the legal academy in 2007, I have written numerous articles examining various aspects of U.S. financial sector regulation, with a special focus on systemic risk containment and structural aspects of U.S. bank regulation. For six years prior to becoming a law professor, I practiced law in the Financial Institutions Group of Davis Polk \& Wardwell and served as a Special Advisor on Regulatory Policy to the U.S. Treasury's Under Secretary for Domestic Finance. I am here today solely in my academic capacity and am not testifying on behalf of any entity. I have not received any federal grants or any compensation in connection with my testimony, and the views expressed here are entirely my own.

The global financial crisis of 2007-09 has left a deep, crippling mark both on the American economy and on the lives of millions of Americans who lost their homes, their jobs, their savings, and their hopes for a better future. It threw the country into a prolonged economic recession, accompanied by growing levels of poverty, inequality, and political discord. According to an estimate by the Federal Reserve Bank of Dallas, the crisis resulted in an economy-wide output loss of up to $\$ 14$ trillion, or $\$ 120,000$ per single U.S. household - both of which amounts will easily double if the broader economic and societal effects of the crisis are permanent. ${ }^{1}$ These output losses triggered a familiar vicious circle of economic stagnation and instability. Faced with steadily declining real incomes, Americans are forced to finance their consumption with an increasingly unsustainable debt, which already reached a record $\$ 13$ trillion mark. ${ }^{2}$ Debt overhang depresses consumer spending, which in turn leads to further contraction in production and employment. $^{3}$

Furthermore, neither economists' estimates nor the actual statistics capture the enormous nonpecuniary or human - costs of the crisis, including the lasting psychological effects of unemployment, underemployment, diminished job security and reduced opportunity. While difficult to quantify, these "hidden" costs of the financial crisis will be borne by the American people for years to come. 
Yet, the very same financial institutions whose reckless profit-seeking created the crisis in the first place were largely protected from the downside of their own excessive risk-taking, because the federal government was compelled to bail them out. Not only did the 2008-09 bailouts effectively exact "an unfair and nontransparent tax upon the American people" but they also significantly undermined public trust in the American capitalist system, thus undermining the system itself. ${ }^{4}$

In this context, the Committee's current efforts to evaluate the role of financial institutions in fostering America's economic growth acquire particular significance. Promoting sustainable, stable long-term growth is an issue of enormous political as well as economic importance. It is the only way of remedying pervasive socially destructive consequences of the financial crisis: only by deliberately and systematically channeling public and private efforts toward the expansion of productive capacity and employment in the real (i.e., non-financial) sector of the national economy can we reverse the crippling effects of the extraordinary wealth transfer from the American taxpayers to the financial industry that the latest crisis laid bare for all to see. There is hardly a greater task facing Congress today, and the Committee's decision to tackle it is a much needed act of public-minded statecraft.

Ironically, however, the financial industry is using this opportunity to mount a massive lobbying effort to achieve the opposite goal: to reverse key post-crisis regulatory reforms enacted with an explicit goal of curbing financial institutions' ability to generate - and then socialize - excessive levels of risk in the financial system. The industry explicitly targets the Dodd-Frank Wall Street Reform and Consumer Protection Act of 2010 (the "Dodd-Frank Act" or the "Act"), the centerpiece of post-crisis financial regulation reform. ${ }^{5}$ In effect, banks are trying to put the Dodd-Frank Act on trial under the rhetorical guise of "fostering economic growth." It is, however, a dangerous misconception to equate economic growth with financial sector deregulation: not only are the two phenomena fundamentally different but, as explained below, they are often mutually exclusive.

It is especially ironic - indeed, astounding - to watch the financial industry complain about its supposedly unbearable regulatory compliance costs, when the industry is doing exceptionally well for itself. All banks and their parent-companies, regardless of size, saw their profits increase steadily during the entire time after the Dodd-Frank Act was passed in 2010. In 2016 alone, banking institutions earned a total of $\$ 175$ billion in net profits. ${ }^{6}$ This is not a sign of a struggling industry.

Of course, it may be reasonable, and even desirable from the public policy perspective, to revisit the continuing efficacy of certain post-crisis laws and regulations or to recalibrate their application to certain small, low-risk financial institutions. If carefully designed and thoughtfully implemented, such recalibration may help to increase the availability of affordable local financing to small businesses in some rural and small-town areas. However, even under the best of circumstances, that possibility alone is not sufficient to support a wide-ranging repeal or rollback of the existing financial laws and regulations. Any such measure would directly and disproportionately benefit large, complex, systemically risky megabanks by removing all meaningful constraints on their ability to destabilize the nation's financial system and, once again, jeopardize American taxpayers' long-term (and even short-term) well-being. It is against this background that the Committee should evaluate every proposal for regulatory reform submitted to it by self-interested industry players. 


\section{FinanCial DeREgUlation Is LiKely To HiNdER, NOT FOSTER, REAL ECONOMIC GROWTH}

The starting point of all deregulatory proposals and arguments advanced by the financial industry is a blanket assertion to the effect that financial institutions' core, if not sole, business purpose is to finance America's economic growth. Accordingly, the argument goes, any regulatory constraint on financial institutions' business activities, by definition, restricts their ability "to serve customers, grow the economy and create jobs." 7 Therefore, an implicit conclusion follows, removing such regulatory constraint will necessarily and automatically improve customers' lives, boost the economy, and create jobs.

It is an inherently faulty argument, insofar as these financial institutions - regardless of their size or other attributes - are privately-owned firms whose overarching business priority is to maximize their own profits and shareholder returns, not the nation's macroeconomic goals. It becomes a deliberately misleading and dangerous argument, however, when used by large financial institutions the bulk of whose profits comes from massive secondary-market trading and dealing operations.

The financial industry's argument either inadvertently conflates or deliberately confounds two very different things: (1) actual growth in the real economy, and (2) mere speculation-driven asset price inflation in the secondary markets.

It is indisputable that what America needs is real economic growth: stable and sustainable long-term growth of the real - i.e. non-financial - sector of the national economy. We urgently need to grow our nation's industrial output and capacity, to facilitate employment- and wealth-generating technological advances, to rebuild and modernize the country's physical and social infrastructure. We also need to ensure that the benefits of these real growth-promoting activities are distributed more equally and fairly, so as to restore the lost strength of America's middle class and to enable lower-income American families to move up the ladder of economic and social success. It is this kind of real, sustainable, structurally balanced, and socially inclusive economic growth that is necessary in order to help the country recover from the post-crisis economic recession.

It is also fundamentally different from the mere asset price inflation, or growth in prices at which various already existent assets - stocks, bonds, commodities, real estate, etc. - are traded in secondary markets. Because increases in market value of such tradable assets at least temporarily increase their owners' individual wealth, the aggregate growth in the market value of all such assets is routinely and erroneously taken as a direct indicator of the aggregate economic "wealth" or national economic "growth." Of course, an increase in the current market price of a particular company's stock may reflect, at least in part, an increase in that company's real-life productivity. But it may also reflect merely the generalized expectations of today's stock buyers that those prices will be even higher tomorrow. In that sense, all asset price inflation is inherently speculative: it is not directly or necessarily linked to actual productive gains in the real economy. ${ }^{8}$

Moreover, speculative asset price inflation, in fact, significantly impedes real economic growth. There are two reasons why that is the case.

First, by making purely speculative investments financially attractive, asset price inflation effectively diverts investment flows away from the primary markets in which companies raise new capital for expanding their productive capacity. Put simply, investors looking to put their money to use in financial markets face two competing choices: asset price speculation (an easy short-term commitment of capital 
with virtually no "hard" constraints on the upside) or productive investment in the real economy (a longterm commitment of capital with various real-life constraints on potential returns). In that sense, asset price inflation actively undermines the real economy's potential for productive, employment-generating growth that America so desperately needs.

Second, asset price inflation creates instability that directly threatens the economy's ability to operate and grow. When speculation-induced asset price inflation reaches its peak, the inevitable market crash tends to be fast and furious. During these dramatic moments, markets tend to over-correct, sending asset prices far below the levels supported by the "fundamentals." Thus, the ultimate bursting of an unsustainable speculative bubble wipes out not only the artificial, purely speculative gains in asset values but also a lot of real economic wealth. Massive defaults, bankruptcies, business closures, worker layoffs, and other familiar symptoms of a severe "market correction" extinguish both the fruits of the nation's past and the foundations of its future economic growth and prosperity.

To appreciate these dynamics, one need not go as far back as the Great Depression and the Roaring Twenties that led to it. More recent history provides plenty of evidence to the same effect.

In the era of massive financial sector deregulation, throughout the 1990s and all the way until 2008, America's economic boom was based largely on secondary-market asset price inflation. This trend is particularly visible in the period after the enactment of the Gramm-Leach-Bliley Act of 1999 (the "GLB Act"), which repealed the Glass-Steagall Act's prohibition on combining, under the same corporate roof, traditional banking activities and full-blown dealing and trading in securities and other financial (and even non-financial) markets. ${ }^{9}$ Throughout the $1990 \mathrm{~s}$, large financial institutions - both commercial banks and investment banks - lobbied for this "regulatory relief" from the supposedly outdated Glass-Steagall rules, using the familiar rhetoric of "facilitating economic growth" and providing "more choices" and "better services" to their customers.

Once enacted, the GLB Act unleashed an unprecedented consolidation in the financial services industry and the emergence of a handful of extremely large FHCs that began aggressively growing their largescale trading and dealing operations in securities, derivatives, short-term money-like instruments, and physical commodities. ${ }^{10}$ Their core banking operations, while still a critical point of access to public subsidy, quickly lost their status as the "core" source of profitability. ${ }^{11}$ In the short nine years between the enactment of the GLB Act and the near-collapse of the financial markets in the fall of 2008, these universal megabanks have effectively turned into universal dealers making secondary markets in everything and anything that could be quantified and turned into a trading asset. A result of this unprecedented growth of secondary market speculation was an equally unprecedented asset price inflation - a story aptly told by many an expert already.

For present purposes, however, one point deserves special emphasis: As secondary market trading volume, stock price indices, and financial firms' profits were all going up, domestic industrial production declined, manufacturing jobs were massively outsourced overseas, wages stagnated, and consumer debt (itself converted to a "securitized" trading asset) ballooned. In effect, this "financialization" of the American economy represented an unprecedented transfer of wealth from the real economy to the increasingly speculation-oriented financial sector. ${ }^{12}$ The systematic redistribution of wealth from the Main Street makers to Wall Street takers was starkly exposed when the speculative craze - particularly, in mortgage-backed securities, underlying mortgage loans and houses - finally triggered the world's first truly systemic financial crisis. ${ }^{13}$ To protect the economy from collapse, American taxpayers were forced 
to bail out the same megabanks that fueled - and profited from - the crisis-inducing asset price inflation. Today, financial institutions are doing very well, in terms of profits and returns on their shareholders' equity. ${ }^{14}$ But the middle class and poor Americans, whose livelihood is tied to the real economy, continue to bear the full burden of the sluggish post-crisis recovery.

The centerpiece of post-crisis regulatory reform, the Dodd-Frank Act, aims to minimize the likelihood of recurring speculative asset price inflation. Thus, the Dodd-Frank Act established a new systemic oversight body, the Financial Stability Oversight Council ("FSOC"). ${ }^{15}$ The Act mandated enhanced prudential supervision of so-called "systemically important financial institutions" ("SIFIs"), which includes large bank holding companies ("BHCs") with at least $\$ 50$ billion in assets and certain non-bank financial institutions designated as SIFIs by FSOC. ${ }^{16}$ As part of such enhanced prudential supervision, SIFIs are required to maintain higher capital and liquidity buffers, conduct regular stress tests, and prepare and submit to regulators comprehensive resolution plans ("living wills").

Among other things, these heightened requirements are designed to limit the ability of large financial conglomerates to create dangerous levels of risk through their massive dealing and trading operations in secondary markets. By restricting SIFIs' ability to fuel destabilizing asset price inflation, the Dodd-Frank regime of enhanced prudential supervision also helps to channel investment away from socially destructive speculation (secondary markets) and toward productive investment in the real economy (primary markets). While it is not commonly perceived or discussed in these terms, this potential "channeling" effect of the Dodd-Frank Act on real economic growth should not be underestimated. Put simply, if investors find fewer lucrative opportunities in speculative assets trading, they will direct more of their money into non-speculative investments.

It is, therefore, no surprise that large financial conglomerates - Wall Street megabanks that dominate and profit from secondary market trading and dealing activities - are now asking Congress to reverse all of the major post-crisis regulatory reforms that threaten their ability to promote speculative asset price inflation. Rhetorically, these financial institutions are deliberately using the language of "fostering economic growth" and "creating jobs," ostensibly through lending to "small businesses" and "American families." Strategically, they are taking advantage of the fact that many smaller BHCs, regional lenders without meaningful trading operations, voice their own, qualitatively different, concerns about the unintended consequences of applying SIFI regulation to their more traditional banking-based business models. Neither of these clever tactics should sidetrack the Committee in its deliberations on how to foster sustainable, stable growth in the real economy, as opposed to mere speculation in secondary markets.

\section{The FinANCIAL Industry's DEREgulatory Proposals WiLl Not Foster ReAL ECONOMIC GROWTH}

The financial industry has submitted numerous letters and proposals for deregulatory reforms that would ostensibly promote economic growth. A comprehensive or detailed analysis of all such letters and proposals would make my testimony unwieldy. Instead, I will focus on the industry's key deregulatory proposals targeting the Dodd-Frank's regime of enhanced prudential supervision, including the process of SIFI designation and supervisory stress testing. While these proposals offer clear potential benefits from the standpoint of financial institutions' own profitability and stock price (at least in the short run), the financial industry failed to establish how the proposed deregulatory measures would promote sustainable long-term growth of the American economy. 


\section{A. Rolling Back Enhanced Prudential Regulation Will Promote Speculation-Driven Asset Price Inflation, Not Real Economic Growth}

The financial industry's proposals nearly uniformly try to make a case that one of the key impediments to creating American jobs and fostering economic growth is the Dodd-Frank Act's explicit focus on systemic risk prevention. This argument targets the FSOC's general authority to designate SIFIs, the process and criteria for application of enhanced prudential standards, the substance of such standards, and the federal regulators' ability to exercise discretion in implementing their statutory oversight responsibilities. The principal justification for this sweeping attack on the core features of the post-crisis regulatory regime is that it increases individual financial institutions' costs of compliance, compared to their pre-crisis regulatory compliance costs.

This line of argument lacks merit.

Every regulation, by definition, increases regulated firms' costs of doing business: such costs may include both the direct expenses of complying with regulations and the foregone profits from the prohibited or restricted activities. Child labor laws, environmental regulations, anti-fraud rules all raise costs of doing business for those private firms that stand to profit from activities the society deems undesirable. The mere imposition, via regulation, of additional private costs is not an "unintended consequence" that must be avoided: it is the principal mechanism of protecting the public from potential harm caused by profitseeking private actors.

The appropriateness of additional private costs of regulation, therefore, must be weighted not against preregulation private costs but against potential public costs likely to accrue in the absence of regulation. None of the financial industry's proposals offer any discussion, let alone quantification, of the full public costs of rolling back the Dodd-Frank regime of systemic oversight. In that sense, while styled as public policy proposals, these are merely requests for special private benefits.

The rhetoric of "promoting economic growth" is meant to mask this fundamentally self-interested nature of the financial industry's requests for deregulation. As discussed above, removing prudential restrictions on large financial institutions' risk-taking will hinder, not promote, the kind of real economic growth that the American people so urgently need. It will spur precisely the kind of secondary market speculation and asset price inflation that enriches Wall Street megabanks and further decimates America's real productive capacity.

Notably, all of the financial industry's proposals to roll back Dodd-Frank's enhanced prudential regulation use the same basic rhetorical device: they frame the issue as a clear binary choice between "arbitrary" and "tailored" rules. They claim that existing SIFI determination criteria (in particular, the \$50B asset size threshold for treating BHCs as SIFIs), the Federal Reserve's supervisory stress tests, and even the long-standing CAMELS rating system are "arbitrary" and should be either repealed or replaced with something that is "appropriately tailored" to each financial institution's "unique" business and risk profile. ${ }^{17}$

It is not my goal in this testimony to engage in any technical disputes regarding any specific capital requirements or stress test methodologies. My comments go to the overarching misconception that the 
industry actors' concerted (possibly coordinated?) use of the false dichotomy - "arbitrariness" vs. "tailoring" - engenders.

\section{“Tailored” SIFI Determination Is A Path to Eliminating SIFI Oversight}

Generally, setting a specific numeric threshold as a jurisdictional device - i.e., a criterion for subjecting a particular person to a particular set of legal rules - is not "arbitrary," per se. We all live with a myriad of such fundamentally "arbitrary" but practically necessary threshold-based rules every day: the legal age for voting is 18 , the legal age for drinking is 21 , the individual income tax rates are drawn on the basis of specified income thresholds, and so on. What would happen if we removed all such numerical thresholds as "arbitrary" and replaced them with "tailored" determinations seeking to establish with complete precision every single person's "unique" individual ability to exercise voting rights, consume alcohol, or pay income taxes? In theory, it could make everything better. In practice, however, it would create a far more arbitrary, unpredictable, and chaotic world in which nobody will be able to anticipate - or assess the fairness of - the "uniquely tailored" treatment they receive under voting, drinking, or tax laws. It would also require an enormous amount of government resources to provide sufficiently individualized and "appropriately tailored" determination of every person's many legal rights and obligations. The sheer cost to the public of giving everyone their own "tailored" law will far outweigh any private costs of having to live with "arbitrary" but universally applicable and clearly drawn boundaries.

This simple common-sense logic should be applied to evaluating the financial industry's request to replace the Dodd-Frank's \$50B size threshold for treating BHCs as SIFIs with an "indicator-based" regime of specific case-by-case designation. Midsize banks worried about approaching the \$50B threshold in the future and regional banks that already qualify as SIFIs based on their asset size are especially keen to see this part of the Dodd-Frank repealed and replaced.

Reasonable people may disagree and argue about whether the current size threshold $-\$ 50$ billion in assets - is the right one, or whether a higher or a lower number would be more socially beneficial. On the one hand, as midsize and regional banks argue, their traditional lending-based business model does set them qualitatively apart from Wall Street megabanks with massive and systemically risky trading and dealing activities. The fact that the top six megabanks' size is measured in trillions of dollars further underscores that difference. On the other hand, $\$ 50$ billion is by no means an insignificant number. Only 38 BHCs currently exceed that threshold. It is also instructive to remember that, in the 1980s, savings banks and thrifts - small, local traditional lenders squeezed by competitors - made very similar pleas for regulatory relief. The resulting S\&L crisis showed that hasty deregulation of small lending-oriented financial institutions may create significant risks to the system. ${ }^{18}$

These complexities notwithstanding, the existing regime should not be simply replaced with an "indicator-based" system under which the FSOC would be forced to go through a tedious and inevitably contentious exercise of determining whether any particular BHC's scope, scale, nature, and mix of activities warrants a SIFI designation. While this "flexible" and "individually tailored" approach may sound good in theory, it will significantly undermine the entire post-crisis regulatory framework for safeguarding systemic stability. There are three main reasons why that is the case.

First, mandating an individualized SIFI determination procedure for each potentially systemically significant BHC will impose an enormous, and completely unnecessary, financial and organizational 
burden on FSOC, Federal Reserve, and other regulators. The sheer costs of the "tailored" designation process - hiring and training dedicated personnel and devoting countless amounts of regulators' time and energy to gathering and processing huge amounts of information, most likely over BHCs' constant objections and complaints - will threaten to derail the entire regime of SIFI oversight. It is nearly a certainty that this costly and time-consuming process will effectively preclude both FSOC and the Federal Reserve from exercising their statutory responsibilities as systemic regulators. Notably, financial institutions advocating this measure deliberately ignore these public costs of giving them their own, individually "tailored" supervisory regime. Nor do they undertake to cover all of the additional regulatory costs of the "tailored" SIFI designation process.

Second, individually "tailored" SIFI designation will immediately become vulnerable to the financial industry's other favorite line of attack as being inherently unpredictable, unclear, and non-transparent: in other words, "arbitrary." The very nature of the complex inquiry into various qualitative indicators of systemic riskiness of an individual financial institution is bound to open FSOC to potential allegations of misjudgment, misinterpretation, and misbehavior. The MetLife saga provides a vivid example of that tactic. Given what is at stake for large BHCs, the odds of FSOC being constantly embattled and ultimately incapacitated are unacceptably high. Instituting individually "tailored" SIFI designation process will virtually ensure the next round of industry lobbying, aiming to eradicate the very notion of enhanced SIFI supervision as ostensibly non-administrable in practice.

Third, there is significant danger that loosening the SIFI designation process, primarily to accommodate the demands of midsize and regional banks and BHCs, will pave the way for large Wall Street megabanks to seek additional deregulatory measures specially "tailored" to enable them to expand their lucrative secondary-market trading and dealing operations. While such activities are precisely what creates unsustainable levels of risk in the financial system, it will be much more difficult for lawmakers and (already significantly weakened) regulators to resist what will likely be framed as simply "further tailoring" of supervisory rules.

\section{Attacks on "Arbitrary" Stress Testing are Attacks on Supervisory Discretion}

Ironically, even as the financial industry ostensibly wants FSOC to exercise individualized judgment instead of applying "arbitrary" generalized rules in the context of SIFI designation, the same industry vehemently attacks the exercise of individualized judgment - or supervisory discretion - by the Federal Reserve in the context of supervising SIFIs. The key target of this attack is the post-crisis regime of supervisory stress testing.

The largest megabanks appear particularly determined to limit the Federal Reserve's ability to conduct meaningful Comprehensive Capital Analysis and Review ("CCAR"), mandated by the Dodd-Frank Act. Among other things, they seek to

- $\quad$ subject the Federal Reserve's annual stress test scenarios to a 30-day notice and comment period under the Administrative Procedure Act;

- restrict the Federal Reserve's ability to use its own independent assumptions in constructing test models;

- mandate advance publication of the Federal Reserve's stress test models for "peer review;" 
- restrict the use of the Federal Reserve's own models merely to a "supervisory assessment" of banks' own models; and

- $\quad$ eliminate CCAR's qualitative assessment for all banks. ${ }^{19}$

If implemented, these industry-advocated changes will effectively nullify the CCAR regime. The principal reason for subjecting SIFIs to both internal and supervisory stress tests is to create a reliable early-warning mechanism for identifying potential weaknesses in the firm's capital planning and management. Forcing the Federal Reserve to disclose ahead of time its stress test models will enable financial institutions "to manage to the test," thus defeating the whole purpose of stress testing. Moreover, subjecting its test scenarios or modeling methodologies to public notice and comment will inevitably create unnecessary delays in the implementation of stress tests. It will impose potentially prohibitive additional costs on the Federal Reserve, burdened with the duty to respond to numerous industry comments and criticisms. Finally, relegating the Federal Reserve's models to a mere back-up reference function will render the entire exercise inherently unreliable.

In sum, what the financial industry is advocating here is not a "more robust and transparent" stress testing process, but a de facto sidelining of the Federal Reserve by forcing it to surrender its key supervisory function to SIFIs themselves. Doing so will significantly endanger the country's financial stability and increase the likelihood of another systemic crisis. Accordingly, it will hinder, not promote, America's long-term economic growth.

\section{B. There Is No Evidence that Financial Deregulation Is Necessary To Foster Economic Growth}

Financial institutions' deregulatory proposals claim that the post-crisis regime of enhanced prudential oversight directly prevents them from extending more loans to small businesses and struggling American families. They routinely assert that the more stringent capital requirements and the higher costs of regulatory compliance are the principal, if not the sole, reason why banks cannot increase their financing of productive economic enterprise.

Constant repetitions of this blanket assertion are intended to condition the audience - including the Members of this Committee - to associate the rollback of Dodd-Frank (something the financial industry wants) with the creation of domestic manufacturing jobs (something the American people need). It is calculated to propagate dangerous confusion about the real causes of financialization, ongoing erosion of America's industrial base, rising poverty and inequality, and other social and economic ills of the last several decades. In essence, the industry wants us to believe that forcing Citigroup and Bank of America to finance just $5 \%$ of their multi-trillion-dollar high-risk assets with common shareholder equity is the root of all of the nation's economic woes.

This is an incredible claim. There are three main reasons why it is fundamentally false:

- First, capital regulation does not reduce banks' cash available for lending: that notion is based on a fundamental misunderstanding of what bank capital is.

- Second, banks are not short of cash necessary to expand their lending: banks' soaring profits and record dividend payments in recent years show there is plenty of cash they could, but choose not to, lend out. 
- Third, there is no evidence that banks are striving to increase lending that would foster the economic growth: the industry offers no proof (beyond simple assertions) that individual banks' asset allocation decisions are driven, in any meaningful way, by their desire to raise the rate of growth in the real economy. In the absence of such evidence, banks' deregulatory demands should not be taken as bona fide proposals to foster America's long-term economic growth.

\section{Enhanced Capital Levels Do Not Restrain Availability of Credit}

Higher capital requirements have nothing to do with reducing money available to banks for lending and productive investment. Capital is not cash in the vault. It is merely an accounting concept, the amount of shareholder equity on a bank's balance sheet: i.e., amount contributed by the bank's shareholders and not borrowed from depositors and other creditors. ${ }^{20}$ Banks do not "hold" capital in the same way as they "hold" cash or gold - and in the exact same way as Exxon-Mobil or Microsoft are never said to "hold" their shareholder equity. Capital is simply what the owners of the corporation would receive if the corporation liquidated all of its assets and repaid all of its debts. In that sense, capital is a critical equity cushion that protects corporations' - including banks' and BHCs' - creditors from losses. It is only because financial institutions' creditors are explicitly or implicitly protected from such losses by the federal government that banks and BHCs are allowed to operate with much thinner equity cushions than would be sustainable in our free capitalist market. ${ }^{21}$

It is therefore nonsensical to claim that reducing this creditor-protecting, loss-absorbing equity cushion will somehow "free up cash" for bank lending - and, specifically, for lending to small businesses and credit-needy Americans. How much a bank is willing or able to lend is a complex asset allocation decision that is driven primarily by considerations of bank's own profitability: "Should we extend a longterm loan to a risky small startup, or should we use that money to increase our fee revenues from shortterm derivatives trading?" The impact of this decision on the bank's regulatory capital ratios or stress test results may be an important factor in its choice between lending and trading, but only insofar as it affects - indirectly and in combination with many other factors - that bank's overall profits.

In other words, capital regulation constrains banks' (individually rational) propensity to choose "high risk, high return" assets and limits their ability to maximize shareholder profits by jeopardizing creditors. These regulatory capital constraints, however, still leave plenty of room for banks to choose whether to finance productive economic enterprise or to channel money into secondary market speculation. To the extent the latter increases short-term shareholder returns, it remains a potentially more attractive choice. The largest banks' massive shift into secondary market trading and dealing, especially after the passage of the GLB Act, aptly illustrates that dynamic.

If Congress grants these largest banks' demands to weaken existing capital requirements, supervisory stress testing, and other elements of enhanced prudential regulation and supervision, it will affirmatively sanction virtually unconstrained growth in the volume and speculative riskiness of banks' trading and dealing activities, not traditional "small-business" lending. That, in turn, will spur precisely the kind of speculation-driven asset price inflation that threatens the stability of the American financial and economic system and undermines the country's long-term economic growth. 


\section{Banks Are Not "Short of Cash" for Lending}

According to the FDIC statistics, the U.S. banking industry has fully recovered from the crisis and is doing exceedingly well. Thus, in the first quarter of this year, nearly $96 \%$ of all U.S. insured depository institutions were profitable; their average return on equity stood at a healthy $9.37 \%$; and their total quarterly income reached $\$ 44$ billion, which is $12.5 \%$ higher than a year earlier. ${ }^{22}$ Insured banks' total net income in 2016 exceeded $\$ 171$ billion. ${ }^{23}$ BHCs are also turning handsome profits. For example, in the last quarter of 2016, the total quarterly income of just the top six BHCs - JPMorgan Chase \& Co., Bank of America Corp., Wells Fargo \& Co., Citigroup, The Goldman Sachs Group, and Morgan Stanley exceeded $\$ 24$ billion. ${ }^{24}$

These profits directly increase banks' and BHCs' shareholder equity - the capital cushion that is a subject of so many of the industry's complaints - and are easily available for use in their lending or other growthpromoting activities. However, it appears that a big chunk of these profits is instead being distributed to the banking institutions' shareholders, in the form of cash dividends and share repurchases. Thus, in 2016, federally-insured banks alone returned to their shareholders $\$ 103$ billion in cash dividends, ${ }^{25}$ a number second only to the record high of $\$ 110$ billion in cash dividends they paid in 2007 , the last full pre-crisis year. $^{26}$

By any measure, $\$ 103$ billion is an enormous amount of money that could be used both (1) to increase banks' total loss-absorbing and risk-reducing regulatory capital cushion, and (2) to finance small familyowned businesses, entrepreneurial startups, medium-size industrials, aspiring students, and struggling families. In other words, using \$103 billion of banks' profits to increase lending to productive economic enterprise would advance both (1) the public interest in having a safer and more efficient system of credit allocation, and (2) the banks' self-professed interest in fostering economic growth and creating American jobs. Yet, banks chose not to go that socially beneficial route.

It is astonishing to see that, after voluntarily sending all that money to shareholders, the banking industry complains that the additional cost of complying with post-crisis regulations "takes capital away from small business loans, home purchases and other productive uses."27 "Every dollar spent on hiring compliance attorneys," the argument goes, "is potentially $\$ 10$ dollars of loans that could be made to improve someone's economic opportunity." ${ }^{28}$ As the dividend numbers cited above show, every dollar diverted away from banks' regulatory compliance would most likely improve only bank shareholders' and managers" "economic opportunity." In fact, using the same mathematical logic, it follows that, in 2016 alone, banks have willingly deprived the real economy of a whopping \$1.03 trillion in "small business loans, home purchases and other productive uses."

It is not my contention that banks should never declare shareholder dividends. The key point here is that bank dividend payouts expose the fundamental falsity of the industry's claims to the effect that excessive regulatory costs deplete banks' resources and prevent them from financing real economic growth. Banks have plenty of extra money for expanding their lending. They choose not to lend that money, instead "returning capital" to their shareholders. That is because stable and high dividends increase individual banks' stock prices, which directly benefits not only bank shareholders but also their executives and managers. Higher stock price translates directly into higher bonuses. Higher volume of small-business lending does not. 
This basic fact about banks' use of available capital may explain why these institutions - particularly, the largest Wall Street megabanks - are waging such an adamant campaign against CCAR, "living wills," and other key elements of the Dodd-Frank's systemic risk prevention regime. Under the current regime, SIFIs' ability to pay shareholder dividends or repurchase their own shares is expressly conditioned on supervisory approval, based in part on the results of the latest stress tests. Not meeting supervisors' expectations, therefore, limits their ability to pay dividends and depresses their stock price. It is telling, for example, that securities analysts and investment advisers have been buzzing about Citigroup's and Bank of America's recent and expected future hikes in dividend payouts after both of these firms performed better in the CCAR tests. ${ }^{29}$ As one expert put it, "The ability to pay dividends is currently a hallmark of strength in the sector." ${ }^{30}$ Accordingly, deregulatory rollback of the Federal Reserve's stress testing and other prudential regulations is expected to enable Citigroup, Bank of America, and other SIFIs to raise their dividends and share repurchases, thus lifting the value of their stock. ${ }^{31}$

Thus, it appears that market experts have no confusion about the real benefits of massive financial deregulation: it will increase banks' profits, dividend payouts, and stock prices. Whether or not it will also promote the country's long-term economic growth does not seem to be part of the conversation.

\section{There Is No Evidence That "Fostering America's Economic Growth" Is A Meaningful Factor In Banks'}

\section{Business Decisions}

It is, of course, possible that, while returning massive amounts of capital to shareholders, banks and BHCs are nevertheless genuinely dedicated to their self-declared mission of financing America's real economic growth. Rather than take their word for it, however, the Committee should require specific, robustly documented and empirically supported, evidence that that is indeed the case.

For example, the Committee should ask each financial institution asking for regulatory relief to provide specific, quantified, and fully documented answers to the following questions:

- What was your institution's specific (i.e., quantified) annual contribution to the growth of your local, regional, and/or national economy, in the period between 2010 and 2017 (after the enactment of Dodd-Frank)? What was it in the pre-Dodd-Frank period between 2000 and 2009?

- How much additional annual contribution to the growth of your local, regional, and/or national economy would your institution have made, but was prevented from making directly as a result of [insert a specific regulatory provision of the Dodd-Frank regime]?

- In each year since 2010, what was the aggregate amount of commercial and industrial (C\&I) loans that your institution refused to extend, solely because of [insert a specific regulatory provision of the Dodd-Frank regime]?

- Does your institution have an enterprise-wide strategy for facilitating domestic job-creation and promoting the growth of your local, regional, and national economy? What are the core elements of that strategy?

- How often does your institution's Board of Directors and top management discuss the institution's performance in implementing that strategy?

This type of targeted inquiry would help to (1) establish the credibility of the financial industry's claims; and (2) discover the real link, if any, between financial institutions' deregulatory agenda and the country's real economic growth. Presently, none of the financial industry's numerous deregulatory proposals 
establish that link, relying instead on purely declarative rhetoric. They then demand effective removal of key regulatory safeguards against systemic financial crises, solely on the strength of that rhetoric.

Assessing the public costs and benefits of any such deregulatory proposals, however, requires ascertaining that such steps are actually - and not just rhetorically - going to generate substantial growth in the country's real economy.

It is unlikely that any financial institution will be able to produce satisfactory answers to any of these questions. As private shareholder-owned firms, these institutions' primary concern is their own profitability, not the overall performance of the American economy. They simply do not track, and are not equipped to track, the relevant macroeconomic data: measuring and worrying about such data is the government's responsibility, an inherently public task. That means that determining what should be done to spur America's economic growth - and whether relaxing any of the existing financial regulations should be a part of that endeavor - is also an inherently public responsibility. The financial industry's attempts to usurp or sidetrack the process of public deliberation on such an important matter should therefore be subjected to intense scrutiny.

\section{Broader Structural Solutions ARe NeEded To Channel Capital Into Productive ECONOMIC ACTIVITY AND SUSTAINABle GrowTH}

The Dodd-Frank regime of systemic oversight and enhanced prudential supervision of SIFIs correctly aims to limit potentially destabilizing speculation and asset price inflation in secondary markets. To the extent it strengthens the resilience and stability of our financial system, it lays down an important foundation for the nation's long-term economic growth. However, simply limiting the opportunities for diverting capital into speculative trading is not sufficient to spur and sustain such growth in practice. It is equally important to ensure that a significantly greater share of available financial capital is actively and consistently flowing into long-term productive investment. In other words, it entails cultivating new sources of, and creating new avenues for profitably deploying, truly "patient” capital.

Abundant patient capital is what enables construction of large-scale physical and social infrastructures, supports transformative R\&D projects, generates productivity gains, and creates sustainable well-paying jobs throughout the nation. By the same token, the chronic shortage of patient capital - and persistent glut of speculative capital - is the key reason for the sluggishness of America's real economy today.

Incentivizing investor "patience" on the scale needed to spur the nation's long-term economic growth, however, is a difficult task that cannot be reduced simply to a few deregulatory or tax-relief measures. Nor can it be left to the private sector alone. Private investors' time horizons and risk tolerance levels are inherently limited by the finite nature of their economic resources and their biological lifespan. It is fundamentally rational for private investors to prefer shorter-term investments, which entail less unforeseeable future risk and promise returns within such investors' reasonable lifetime horizons. Private investors' short-term bias, therefore, is not a deviation from market rationality; it is a built-in feature of such rationality.

Overcoming investor short-termism and facilitating the formation of "patient" capital requires new, more effective forms of public-private partnership. The public component of such partnership will bring into the investment process a number of unique advantages that public instrumentalities enjoy when they act as market participants: their vast scale, high risk tolerance, lengthy investment horizons, and direct backing by the full faith and credit of the United States. Combining these unique capacities of a public 
investor with private investors' informational agility, superior knowledge of local conditions, and market expertise will help to channel both private and public resources into the critical growth-inducing projects. This new, patient public-private capital will finance the building of new roads, bridges, high-speed train lines, clean energy networks, and next-generation industrial plants. It will also create new well-paying jobs, offer new educational opportunities, and unleash new entrepreneurial energy of the American people.

My colleague, Professor Robert Hockett, and I have developed a specific proposal for creating this new kind of infrastructural growth-oriented public-private partnership. A White Paper detailing our proposal is attached as an Appendix to this testimony.

It is this kind of programmatic reform - not a massive rollback of the Dodd-Frank Act - that the American economy and the American people need. I urge the Committee to rise to this challenge and not allow banks' self-serving deregulatory demands to distract its attention from what really matters to the American economy and the American public.

\section{CONCLUSION}

Promoting sustainable, socially inclusive long-term growth in America's real economy is a task of enormous public significance. Massive financial deregulation urged by the banking industry, however, will not foster such real economic growth: it will merely spur speculation-driven asset price inflation in secondary markets. That is what generates Wall Street's greatest short-term profits and causes wealthand growth-destroying systemic crises. Weakening regulatory standards and effectively incapacitating FSOC, the Federal Reserve, the Consumer Financial Protection Bureau, and other federal regulators will put us much closer to another financial disaster.

Contrary to the financial industry's assertions, massive dismantling of the Dodd-Frank regime of systemic regulation will not benefit small businesses and struggling families across America. There is no evidence that the additional cost of banks' regulatory compliance with post-crisis regulations actually depletes banks' resources and/or diverts them away from productive uses. Despite their complaints about regulatory costs, American banking institutions are highly profitable and awash in cash, which they could use for lending to small businesses but instead choose to return to their shareholders in the form of dividends and share repurchases. Against that background, it is impossible to take the industry's attacks on Dodd-Frank seriously.

The Committee should, therefore, reject the financial industry's unsubstantiated claims and requests for massive deregulation and demolition of the Dodd-Frank Act. The Committee should focus its attention on finding real solutions to the real problems associated with speculative short-termism and persistent misallocation of capital, which impede economic growth. Devising such solutions is challenging but necessary in order to make finance serve the nation's long-term economic goals. 
${ }^{1}$ David Luttrell, Tyler Atkinson, Harvey Rosenblum, Accessing the Costs and Consequences of the 200709 Financial Crisis and Its Aftermath, DALlASFED ECONOMIC LETTER, Vol. 8, No. 7 (Sept. 2013), available at https://www.dallasfed.org/research/eclett/2013/el1307.cfm, at 1-2.

${ }^{2}$ See, Matt Scully, Trumps' America Is Facing a \$13 Trillion Consumer Debt Hangover, BLOOMBERG.COM (6 June 2017), available at https://www.bloomberg.com/news/articles/2017-0606/trump-s-america-is-facing-a-13-trillion-consumer-debt-hangover?srnd=157391092.

${ }_{3}^{3}$ See, Robert Hockett \& Richard Vague, Debt, Deflation, and Debacle: Of Private Debt Write-Down and Public Recovery (2013), available at https://www.interdependence.org/wpcontent/uploads/2013/04/Debt-Deflation-and-Debacle-RV-and-RH1.pdf.

${ }^{4}$ Luttrell et al., supra note 1 , at 3.

${ }^{5}$ Dodd-Frank Wall Street Reform and Consumer Protection Act of 2010, Pub. L. No. 111-203, 124 Stat. 1376 (2010) (codified at 12 U.S.C. $\S 5301$ et seq. (2012)).

${ }^{6}$ The total number for 2016 is the sum of the revenant quarterly numbers. See, Federal Reserve Bank of New York, Quarterly Trends for Consolidated U.S. Banking Organizations, available at https://www.newyorkfed.org/medialibrary/media/research/banking research/quarterlytrends2016q4.pdf?1 $\underline{\mathrm{a}=\mathrm{en}}$,

${ }^{7}$ Letter to The Honorable Michael D. Crapo and The Honorable Sherrod Brown from Francis Creighton, Executive Vice President of Government Affairs of Financial Services Roundtable (Apr. 14, 2017) [the "FSR Letter"], at 1.

${ }^{8}$ The fundamental logic of speculative manias and crashes has been explained and documented many times. See, CHARles P. KindleBerger \& ROBERT AliBER, MANIAS, PANICS, AND CRASHES: A HiSTORY OF FinANCIAL CRISES (2005); ERIK GERDING, LAW, BUBBLES, AND FINANCIAL REGULATION (2013).

${ }^{9}$ Financial Services Modernization Act (Gramm-Leach-Bliley Act), Pub. L. No. 106-102, 113 Stat. 1338 (1999). .

${ }^{10}$ See, Arthur E. Wilmarth, Jr., The Dark Side of Universal Banking: Financial Conglomerates and the Origins of the Subprime Financial Crisis, 41 CONN. L. REV. 963, 1002-46 (2009).

${ }^{11}$ See, Federal Reserve Bank of New York, Quarterly Trends for Consolidated U.S. Banking Organizations, Fourth Quarter 2016, available at https://www.newyorkfed.org/medialibrary/media/research/banking_research/quarterlytrends2016q4.pdf?1 $\underline{a}=$ en, at 13 .

${ }^{12}$ See, Thomas Philippon, Finance versus Wal-Mart: Why Are Financial Services So Expensive? RETHINKING THE FINANCIAL CRISIS 235 (ALAN BLINDER ET AL., EDS. 2012).

${ }^{13}$ See, Saule T. Omarova, The New Crisis for the New Century: Some Observations on the "Big-Picture" Lessons of the Global Financial Crisis of 2008, 13 N.C. BANKING INST. 157 (2009).

${ }^{14}$ According to official statistics, the top 50 largest BHCs' total net income for the last quarter of 2016 was over $\$ 32 \mathrm{~B}$, while their average annualized return on equity was above $7 \%$. Tellingly, the total quarterly income of just the top six BHCs - JPMorgan Chase \& Co., Bank of America Corp., Wells Fargo \& Co., Citigroup, The Goldman Sachs Group, and Morgan Stanley - was over \$24B. Three of these largest institutions had annualized return on equity of almost $11 \%$. Federal Reserve Bank of New York, Quarterly Trends for Consolidated U.S. Banking Organizations, Fourth Quarter 2016, available at https://www.newyorkfed.org/medialibrary/media/research/banking research/quarterlytrends2016q4.pdf?1 $\mathrm{a}=\mathrm{en}$, at 36 .

$\overline{15} 12$ U.S.C. $\$ 5321$.

${ }^{16} 12$ U.S.C. $\$ 5323 ; 5325$.

${ }^{17}$ See, e.g., Letter to The Honorable Michael D. Crapo and The Honorable Sherrod Brown from The Clearing House (Apr. 14, 2017) [the "TCH Letter"].

${ }^{18}$ See, Federal Deposit Insurance Corporation, The S\&L Crisis: A Chrono-Bibliography, available at https://www.fdic.gov/bank/historical/sandl/.

${ }^{19}$ See, TCH Letter, supra note 17. 
${ }^{20}$ For a discussion of bank capital and a compelling argument that capital requirements should be much higher than they are presently, see ANAT ADMATI \& MARTIN HELlWIG, THE BANKER's NEW ClOTHES (2013).

${ }^{21}$ See id.

${ }^{22}$ Federal Deposit Insurance Corporation, Statistics At A Glance, As of March 31, 2017, available at https://www.fdic.gov/bank/statistical/stats/.

${ }^{23}$ FDIC Quarterly Banking Profile, Fourth Quarter 2016, available at https://www.fdic.gov/bank/analytical/qbp/2016dec/qbp.pdf, at 7.

${ }^{24}$ Federal Reserve Bank of New York, Quarterly Trends for Consolidated U.S. Banking Organizations, Fourth Quarter 2016, available at

https://www.newyorkfed.org/medialibrary/media/research/banking_research/quarterlytrends2016q4.pdf?1 $\mathrm{a}=\mathrm{en}$, at 36 .

${ }^{25}$ FDIC Quarterly Banking Profile, Fourth Quarter 2016, available at https://www.fdic.gov/bank/analytical/qbp/2016dec/qbp.pdf, at 7.

${ }^{26}$ FDIC Quarterly Banking Profile, Fourth Quarter 2007, available at https://www5.fdic.gov/qbp/2007dec/qbp.pdf, at 5.

${ }^{27}$ FSR Letter, supra note 7 , at 2.

${ }^{28} \mathrm{Id}$.

${ }^{29}$ See, Gemma Acton, These Three US Bank Stocks Are My Top Sector Picks, CNBC.COM (22 Mar. 2017), available at http://www.cnbc.com/2017/03/22/these-three-us-bank-stocks-are-my-top-sectorpicks-analyst.html; Rebecca Keats, Bank of America Declares a Quarterly Dividend, MARKETREALIST.COM (31 Jan. 2017), available at http://marketrealist.com/2017/01/bank-of-americadeclares-a-quarterly-dividend/; Stone Fox Capital, Citigroup: Expect Another Big Dividend Hike To Move Stock, SEEKING ALPHA (4 Jan. 2017), available at https://seekingalpha.com/article/4078558-citigroupexpect-another-big-dividend-hike-move-stock.

${ }^{30}$ Stone Fox Capital, supra note 29.

${ }^{31}$ Id.; Keats, supra note 29. 